\title{
CEREBROPROTECTION BY GERMANIUM COORDINATION COMPOUNDS IN EXPERIMENTAL ACUTE GLOBAL BRAIN ISCHEMIA
}

\author{
V. D. Lukianchuk', I. I. Seifullina ${ }^{2}$, O. E. Martsinko², O. O. Shevchuk ${ }^{3}$ \\ 1 - INSTITUTE OF PHARMACOLOGY AND TOXICOLOGY OF THE NATIONAL ACADEMY \\ OF SCIENCES OF UKRAINE, KYIV, UKRAINE \\ 2 - ODESA I. I. MECHNIKOV NATIONAL UNIVERSITY, ODESA, UKRAINE \\ 3 - I. HORBACHEVSKY TERNOPIL STATE MEDICAL UNIVERSITY, TERNOPIL, UKRAINE
}

Background. Stroke is among the leading causes of death and disability worldwide with rising incidence among young people today. This is the third most common cause of disability-adjusted life-years worldwide

Objective. The present study evaluated the cerebroprotective action of coordination compounds of germanium with underlying global cerebral ischemia in rats.

Methods. Global cerebral infarction was induced by bilateral common carotid artery occlusion. For primary screening we used numerous bis(citrate) germanates (stannates) compounds, which contained different metals: OL1-8, and VITAGERM-1,2,3 and 4. All germanium complexes used were injected intraperitoneally (1 \% aqueous solution at a dose of 50 and $100 \mathrm{mg} / \mathrm{kg}$ in $35 \mathrm{~min}$ after bilateral common carotid artery occlusion). Piracetam was used as a reference drug. Criteria of cerebroprotection efficacy survival of rats (\%), ET50 (median effective time), observational Irwin's test.

Results. Almost all bis(citrate) germanates (stannates), which contained different metals, possessed antiischemic activity of different intensity. The exceptions were cobalt-containing OL-6 and OL-2 compounds. The most significant efficac of all investigated indices (which exceeded even reference drug) was evidenced for VITAGERM-1 - a coordination compound of germanium, diethylenetriaminepentaacetic acid and lithium.

Conclusions. Results of our experiments are the substitution for further more profound pharmacological investigation of VITAGERM-1 for stroke cerebroprotection and its implementation into clinics.

KEY WORDS: global brain ischemia; germanium coordination compounds; screening.

\section{Introduction}

Today stroke is in the top 10 causes of death in the world. It maintains the position as the leading killer, and accounts for more than 6 million deaths annually [1]. In Ukraine, it is near 100000 cases each year, and almost 40000 of them are fatal [2].

Risk of stroke is rising in direct proportion to the patient's age. However, it is observed its rising incidence among young people up to 40 years old in age $[2,3]$. Stroke affects men and women equally and causes major social and economic burdens to society: $80 \%$ of survivors are disabled until the end of life [4]. This is the third most common cause of disability-adjusted life-years worldwide $[4,5]$. More than $80 \%$ of all strokes are ischemic and characterized by occlusion of brain vessel of thrombi or embolus.

The aim of the study is to find the effective cerebroprotector among original synthesized

Corresponding author: Victor Lukianchuk, Professor, Institute of Pharmacology and Toxicology of NAMS of Ukraine, 14 Anton Tsedik Str., Kyiv, 03680, Ukraine

E-mail: Ivdlug@ukr.net

Phone number: +38(044)4569118 coordination compounds of germanium in the experimental model of acute global cerebral ischemia.

\section{Methods}

Experiments were performed on white inbred rats, males and females, $180-220 \mathrm{~g}$ of body weight. Acute brain ischemia was modeled by bilateral occlusion of both common carotid arteries before its bifurcation to external and internal branches under thiopental general anesthesia.

All animals' procedures were carried out according to the rules and requirements of European Convention for the Protection of Vertebrate Animals Used for Experimental and Other Scientific Purposes as well as EU Directives 2010/63/EU.

For primary screening we used numerous bis(citrate)germanates (stannates) compounds, which contained different metals: magnesium bis(citrate) germanate (germacit), mangan bis(citrate) germanate (OL1), cobalt bis(citrate) germanate (OL2), nickel bis(citrate) germanate (OL3), zinc bis(citrate) germanate (OL4), mag- 
nesium bis(citrate) stannate (OL5), cobalt bis(citrate) stannate (OL6), nickel bis(citrate) stannate (OL7), zinc bis(citrate) stannate (OL8), VITAGERM-1 (coordination compound of germanium, diethylenetriaminepentaacetic acid and lithium), VITAGERM-2 (coordination compound of germanium, diethylenetriaminepentaacetic acid and sodium), VITAGERM-3 (coordination compound of germanium, diethylenetriaminepentaacetic acid and potassium), VITAGERM-4 (coordination compound of germanium, diethylenetriaminepentaacetic acid and magnesium). All the compounds were primarily synthesized in the laboratory of Department of General Chemistry and Polymers, I. Mechnikov Odesa National University, headed by prof. I. Seifullina.

All used germanium complexes were administered to rats at the doses according to the results of our previous studies $[6,7]$. We injected them intraperitoneally in the form of $1 \%$ aqueous solution at a dose of 50 and $100 \mathrm{mg} / \mathrm{kg}$ in $35 \mathrm{~min}$ after bilateral common carotid artery occlusion.

As a comparator (reference) drug, Piracetam medication was used (Farmak, Ukraine, $20 \%$ solution in $5 \mathrm{ml}$ ampules). It was injected intraperitoneally at a dose of $350 \mathrm{mg} / \mathrm{kg}$ in 30 min after ischemia. The rats of control group (ischemia without any correction) got equivalent dose of saline.

Criteria of cerebroprotector activity of the studied compounds were: survival of rats (\%) each hour during the first 12 hours, then on the $24^{\text {th }}, 48^{\text {th }}$ and $72^{\text {nd }}$ hours of ischemia; monitoring the clinical signs for $\mathrm{ET}_{50}$ (median effective time the time required for a half as organisms in a toxicity test to reveal the nonlethal response). It was evaluated to be $E T_{50}=f(\mathrm{~N} / 2)$ by interpolation of data of lethality time to mathematical function $T=f(N)$, where $T$ is the time of animals death, $N$ - the number of animals. Neurological status was assessed by Irwin's test in the model of acute brain ischemia and administration of germanium compounds. The primary observation test was used for rodents to assess acute toxicity of a test agent and its effects on behavior and physiological function [8,9].

Statistical analysis. Statistical analysis of animals' survival have been carried out using the nonparametric criterion Fisher's exact test and average time of lifespan by use of t-criterion of Students' test. All data were presented as M (mean) $\pm \mathrm{m}$ (standard error). A probability level ( $p$ value) of less than 0.05 was considered to be statistically significant.

\section{Results}

The results obtained in the screening model of global brain ischemia are presented in the Table 1. Almost all bis(citrate) germanates (stannates), which contained different metals, possessed anti-ischemic activity of different intensity. The exception was the OL-6 compound, which comprised cobalt. Even at the dose of $50 \mathrm{mg}$ per $\mathrm{kg}$ in this group during the first hour of occlusion of aa. carotica communes the rate of rats survival was only $28.5 \%$ opposite to $100 \%$ in the control group. In addition, the other cobalt-containing compound OL-2 proved very low efficacy for cerebroprotection.

As for the results in Table 1, the most significant efficacy on the $48^{\text {th }}$ hour of the experiment was evidenced for VITAGERM-1 a coordination compound of germanium, diethylenetriaminepentaacetic acid and lithium. The animals' survival in this group was $57.1 \%$ compared to $100 \%$ lethality in the control group. It is important that the anti-ischemic activity of VITAGERM-1 exceeded even the effect of reference drug Piracetam.

To estimate the obtained screening results more profoundly and detail, we suggested and used in our experiment the index of median effective time $\mathrm{ET}_{50}$. According to the results presented in Table 1, $E T_{50}$ for group of rats administered with VITAGERM-1 was $53.31 \pm 2.77$. It was in 7.5, 3.0 times better compared to the control and reference group respectively.

At the same time to make an all-round comparison analysis of the results of screening series we assessed clinical signs of acute ischemia: neurological status of rats, which got the different types of germanium compounds. All data are presented in Table 2.

The rats with stroke, on the model we chose, experienced the severe clinical signs of global ischemia. The animals of control group after occlusion of both carotid arteries became less alert and more passive. It was proved by the indices of emotional condition: grooming decreased up to 0 points, vocalization increased up to 1.4. The tonus of limbs also diminished, ataxia signs increased up to 2.9 points. The character of these neurological changes testified quite a deep injury of brain cortex because of global ischemia. It resulted in the disruption of motor activity in the control group rats: suppression of reactions to touch and knock up to 1.5 and 1.9 points respectively. Brain ischemia also strengthened the tremor up to 2.3 points. The suppression of ptosis reaction in 2.1 times as well as increased 


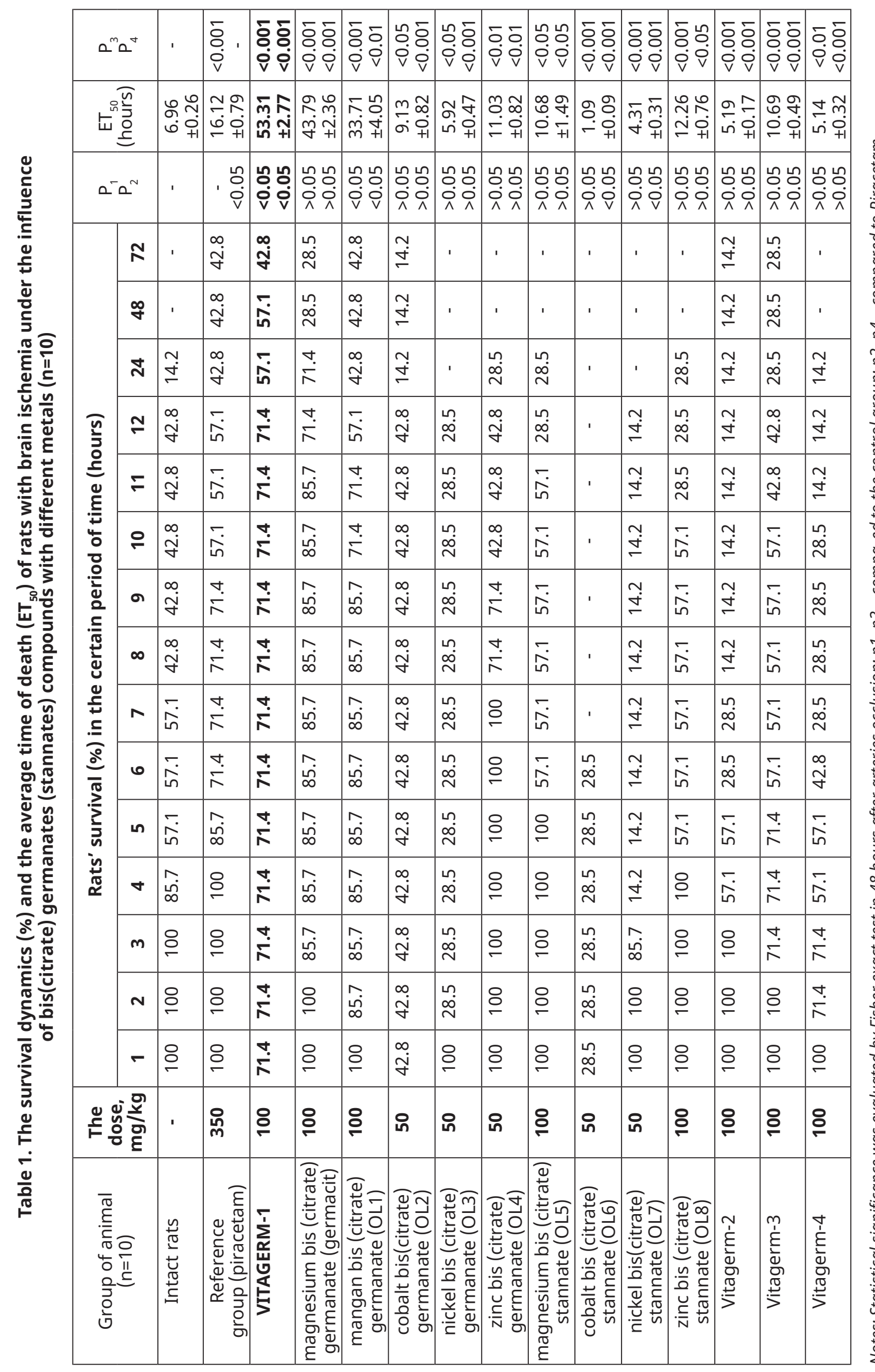




\begin{tabular}{|c|c|c|c|c|c|c|c|}
\hline \multirow{10}{*}{ 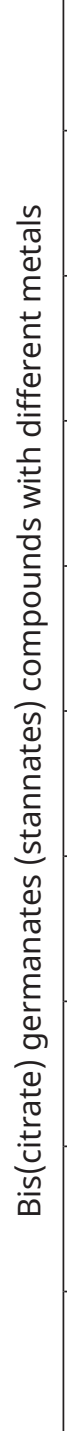 } & ૪-шхәбет!^ & 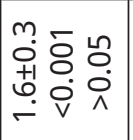 & 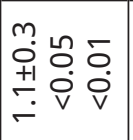 & 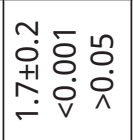 & 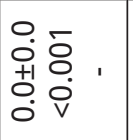 & 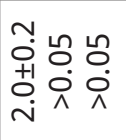 & 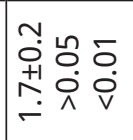 \\
\hline & ع-யләбед!^ & 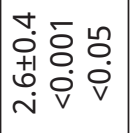 & 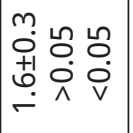 & 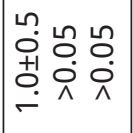 & 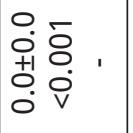 & 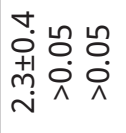 & 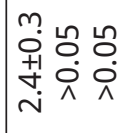 \\
\hline & z-шхәбез!^ & 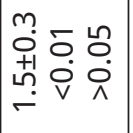 & 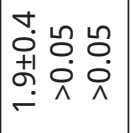 & 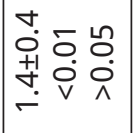 & 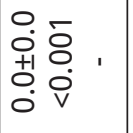 & 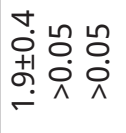 & 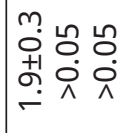 \\
\hline & 8-70 & 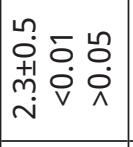 & 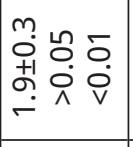 & 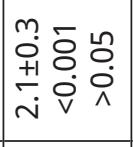 & 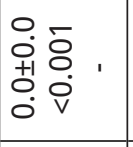 & 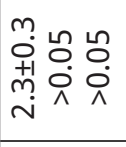 & 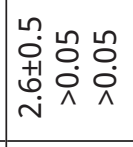 \\
\hline & s-70 & 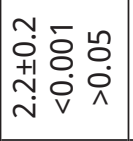 & 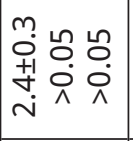 & 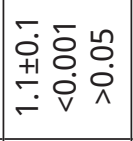 & $\begin{array}{l}0 . \overline{0} \\
0 . \overline{0} \\
\text { †i } \\
0.0 \\
0 \\
0\end{array}$ & 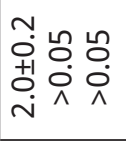 & 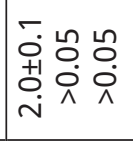 \\
\hline & $t-70$ & 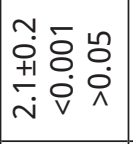 & 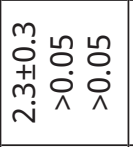 & 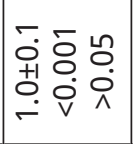 & 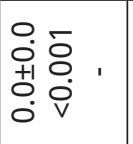 & 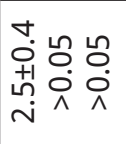 & 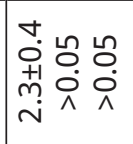 \\
\hline & $z-70$ & $\begin{array}{lll}n & 0 & 0 \\
0 & 0 & 0 \\
+1 & 0 & 0 \\
& 0 & 0 \\
- & 0 & 1\end{array}$ & 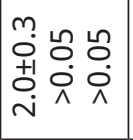 & 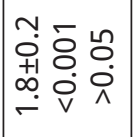 & $\begin{array}{l}0 . \overline{0} \\
0 . \overline{0} \\
+10 \\
0 \\
0\end{array}$ & 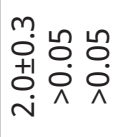 & 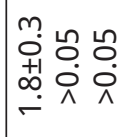 \\
\hline & $l-70$ & 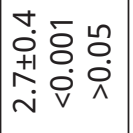 & 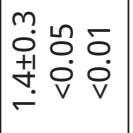 & 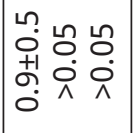 & 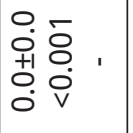 & 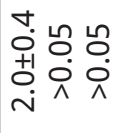 & 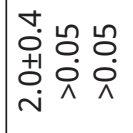 \\
\hline & & 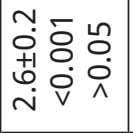 & 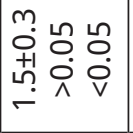 & $\begin{array}{lll}n & 0 \\
0 & - & 0 \\
+1 & 0 \\
0 & 0 & 0 \\
- & 0 & 1\end{array}$ & 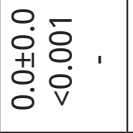 & 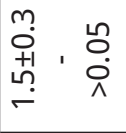 & $\begin{array}{l}m \\
0 \\
o\end{array}$ \\
\hline & เ-шләбет!^ & 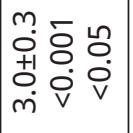 & 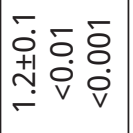 & 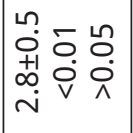 & 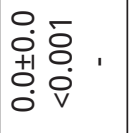 & 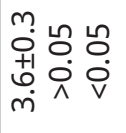 & 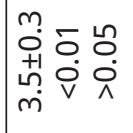 \\
\hline & 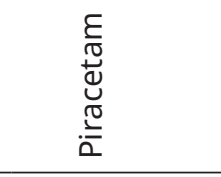 & 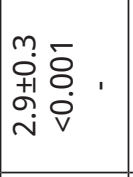 & 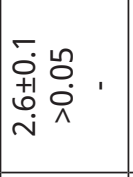 & 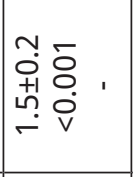 & 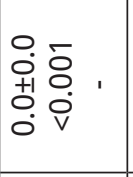 & 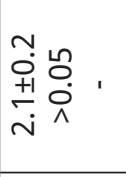 & 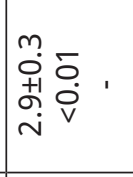 \\
\hline & $\begin{array}{l}\overline{0} \\
\stackrel{0}{ \pm} \\
0 \\
0\end{array}$ & $\begin{array}{l}0 \\
0 \\
0 \\
0 \\
0 \\
0\end{array}$ & $\begin{array}{l}+ \\
o \\
+1 \\
\stackrel{1}{2} \\
\text { in }\end{array}$ & $\begin{array}{l}0 \\
0 \\
0 \\
0 \\
0 \\
0\end{array}$ & $\begin{array}{l}m \\
\stackrel{m}{0} \\
\stackrel{+1}{+} \\
\stackrel{-}{-}\end{array}$ & $\begin{array}{l}m \\
\stackrel{m}{0} \\
\text { +1 } \\
\stackrel{1}{\leftrightarrow} \\
-\end{array}$ & $\begin{array}{l}0 \\
0 \\
+1 \\
o+ \\
-1\end{array}$ \\
\hline & & $\frac{E}{\sum+1} \bar{\alpha} \Sigma$ & $\sum_{i=1}^{E} \bar{\alpha} \Sigma$ & $\frac{E}{\sum+1} \bar{\Omega} \Omega$ & $\sum_{i=1}^{E} \bar{\alpha} \Sigma$ & $\sum_{\sum}^{E} \overline{2} \Sigma$ & $\sum_{i=1}^{E} \bar{\alpha} \tilde{a}$ \\
\hline & әرоدs jeseg & $\theta$ & 0 & $\checkmark$ & 0 & $\checkmark$ & t \\
\hline & 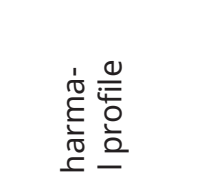 & 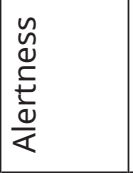 & 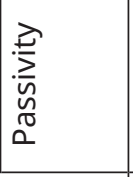 & 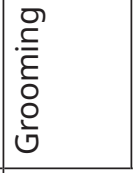 & 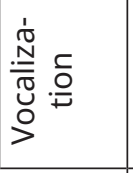 & 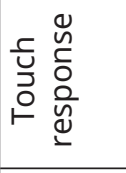 & 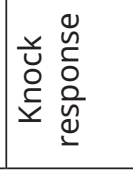 \\
\hline & $\begin{array}{l}\frac{0}{0} \\
\frac{0}{3} \\
\frac{0}{2}\end{array}$ & 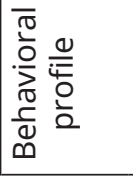 & & ¿ & & 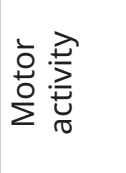 & \\
\hline
\end{tabular}

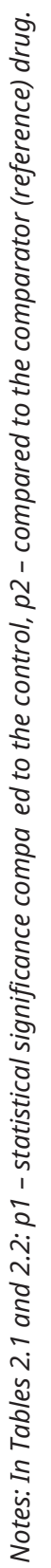




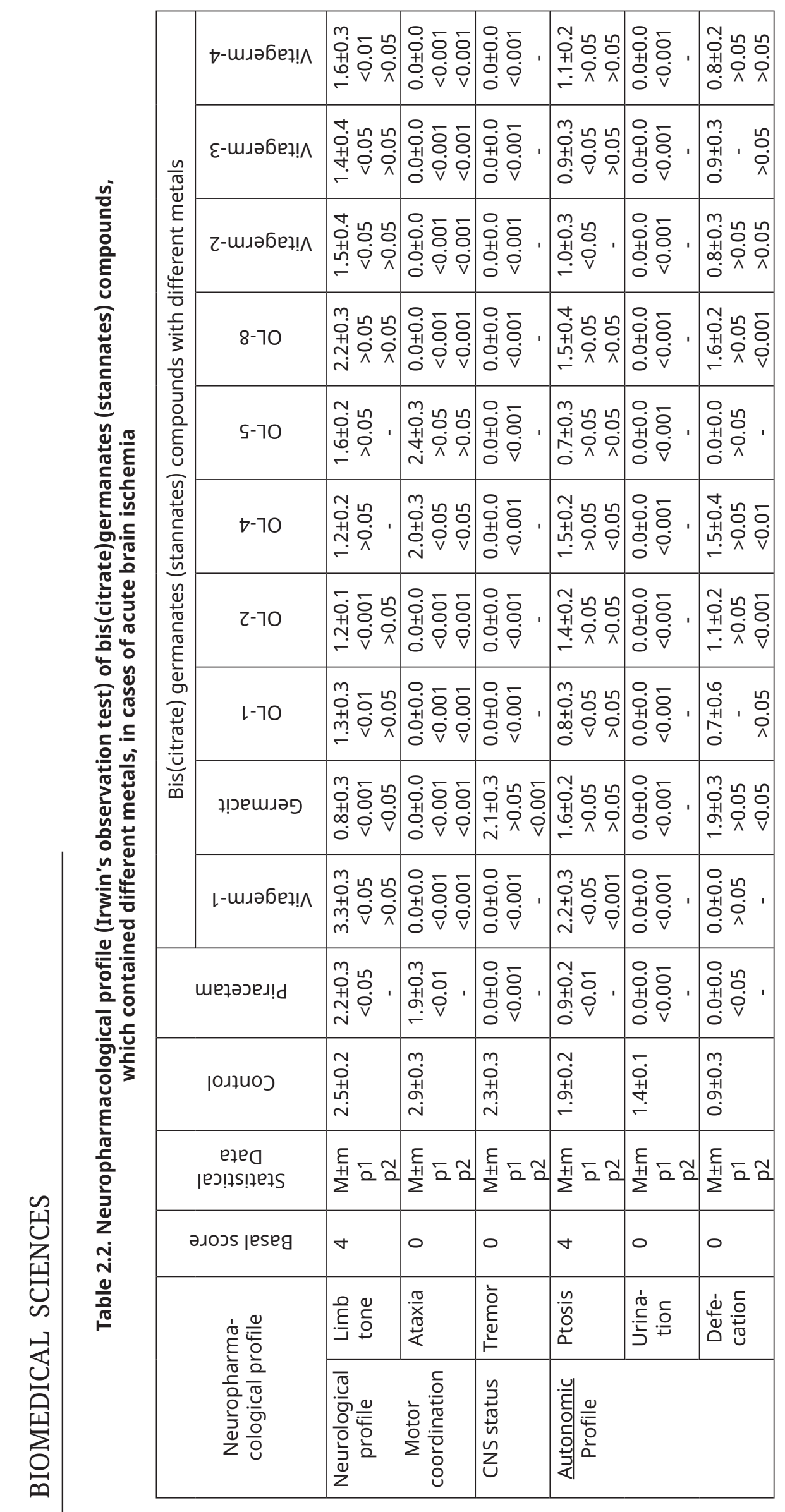


frequency of urination and defecation was evidenced in comparison to the indices of healthy group.

The next stage of our experiment was to estimate the neurological and behavioral profile of rats under the influence of germanium compounds in global brain ischemia model. The most efficient compound was VITAGERM-1 again (Tables 2.1 and 2.2). The significant increase of alertness up to 3.0 points and decreasing of expressiveness of passivity by $41.0 \%$ was fixed in this group compared to the control rats. This investigated compound increased the grooming and normalized the vocalization. Administration of VITAGERM-1 led to absence of ataxia and increase of extremities tonus up to 3.3 points that was nearly the same as the indices of the intact rats. Responses to touch and knock intensified also up to 3.6 and 3.5 points respectively in comparison to the control.

We noticed total positive effects of this germanium compounds in prevention of tremor, urination and defecation; the ptosis rate increased up to 2.2 points.

\section{Discussion}

The pathophysiology of stroke is complex, and involves inflammatory pathways, oxidative damage, apoptosis, energy deficiency etc. The main goal of treatment is to preserve tissues in ischemic penumbra, where perfusion is decreased but sufficient to stave off infarction, and save the neurons (neuroprotection) $[4,5]$.

Ischemic stroke and its consequences is a major public health problem. In spite of huge number of medications to treat it, we still have no perfect one according to the present requirements of safety and efficacy. That is why the search and investigation of newly synthesized organic and other compounds with capability for stroke protection is an actual challenge and target for chemists, pharmacologists, physicians and health professionals.

Numerous bis(citrate) germanates (stannates) compounds with wide spectrum of therapeutic activity are synthesized and investigated today. Our previous experiments proved its low toxicity to warm-blooded species [10, 11, 12]. Use of the rodent models is recommended and approved by different researches for screening and investigating of promising compounds to prevent and treat ischemic brain lesions [13]. In the screening series in the model of global brain ischemia (via occlusion of both common carotid arteries before its bifurcation), it was determined that almost all compounds had potency for stroke protection. Such criteria as survival and median effective time plus Irwin's test results were adequate to evaluate it $[14,15]$. Piracetam was used as a reference drug [16].

Among all investigated bis(citrate) germanate (stannates) compounds, which contained different metals, the most potent anti-ischemic activity was possessed by coordination compound of germanium, diethylenetriaminepentaacetic acid and lithium coded as VITAGERM-1. It was a leader among the germanium compounds according to the analyses of the indices of survival and lifespan of rats from the moment of occlusion of coronary arteries.

Such positive effects were manifested by the highest level of survival and the most favorable clinical course of cerebrovascular blood circulation. Median effective time $\mathrm{ET}_{50}$ in this group exceeded in 7.5 and 3.0 times the index of control and reference group respectively. We noticed total positive effects of this germanium compounds in prevention of disorders of behavioral, neurological and autonomic profiles of rats. Therefore, we concluded the prominent improvement of clinical course of acute brain ischemia under the Vitagerm-1 impact.

We suppose that the presence of the cobalt in structure of OL-2 and OL-5 molecules is responsible for animals lethality during the first hour after the disorder development. Low efficacy of these germanium compounds could be explained by the fact that this metal is a cytochrome P450 inhibitor. The cytochromes P450 (CYPs) enzyme family are crucial in processes of detoxification of the organism, and suppression of its activity is one of the most possible causes of high lethality in cases of experimental global brain ischemia [17].

\section{Conclusions}

Almost all bis(citrate) germanates (stannates), which contained different metals, possessed anti-ischemic activity of different intensity. The exceptions were cobalt-containing OL- 6 and OL- 2 compounds. The most expressive efficacy for all investigated indices (which exceeded even the reference drug) proved for VITAGERM-1 - a coordination compound of germanium, diethylenetriaminepentaacetic acid and lithium.

The results of our experiments are suggested for the substitution for further deeper pharmacological investigation of VITAGERM-1 for stroke cerebroprotection, and its implementation into clinical practice. 


\title{
ПОШУК ЦЕРЕБРОПРОЕКТОРІВ СЕРЕД КООРДИНАЦІЙНИХ СПОЛУК ГЕРМАНІЮ НА МОДЕЛІ ІШЕМІЧНОГО ІНСУЛЬТУ
}

\author{
В. Д. Лук'янчук', І. Й. Сейфулліна², О. Е. Марцинко ${ }^{2}$, О. О. Шевчук ${ }^{3}$ \\ 1 - ДУ «ІНСТИТУТ ФАРМАКОЛОГІЇ ТА ТОКСИКОЛОГІЇ НАМН УКРАЇНИ», КИЇВ, УКРАЇНА \\ 2 - ОДЕСЬКИЙ НАЦІОНАЛЬНИЙ УНІВЕРСИТЕТ ІМЕНІ I. І. МЕЧНИКОВА, ОДЕСА, УКРАЇНА \\ 3 - ТЕРНОПІЛЬСЬКИЙ ДЕРЖАВНИЙ МЕДИЧНИЙ УНІВЕРСИТЕТ ІМЕНІ І. Я. ГОРБАЧЕВСЬКОГО, ТЕРНОПІЛЬ,
}

УКРАЇНA

Вступ. Інсульт залишається однією з провідних причин смертності та інвалідності в усьому світі, однак спостерігається зростання захворюваності серед молоді.

Мета дослідження - скринінгове дослідженння церебропротекторної дії координаційних сполук германію на моделі гострої ішемії у щурів.

Методи. Гостру ішемію моделювали двосторонньою оклюзією загальної сонної артерії. Для первинного скринінгу використовувалися сполуки біс(цитрато)германати (станати), що містили різні метали: OL1-8, VITAGERM-1,2,3 та 4. Усі використовувані комплекси германію вводили внутрішньочеревно (1\% водного розчину при дозі 50 і 100 мг/кг через 35 хв після двосторонньої загальної оклюзії сонної артерії). Пірачетам використовували в якості референс препарату. Критерії ефективності черебропротекції: виживання щурів (\%), ЕT50 (середній час загибелі 50\% тварин), тест Ірвіна.

Результати. Результати, отримані на скринінговій моделі тотальної ішемії головного мозку, показали, що практично всі різнометальні біс (цитрато) германати (станати) володіють антиішемічною активністю різної інтенсивності. Виняток становили сполуки, що містять кобальт OL-6 i OL-2. Найбільш значима ефективність всіх досліджених показників (які перевищували навіть еталонний препарат) була підтверджена для VITAGERM-1 координаційного з'єднання германію, діетилентриамінпентаоцтової кислоти і літію.

Висновки. Результати наших експериментів слугуют підгрунтям для подальшого вивчення сполуки VITAGERM-1 у якості черебропротектора та ії впровадження в клінічну практику.

КЛЮЧОВІ СЛОВА: тотальна ішемія головного мозку; координаційні сполуки германію; скринінг.

\section{References}

1. World Health organization WHO updates fact sheet on Top 10 causes of Death. 27 Jan 2017.

2. Zozulia IS. Epidemiology of cerebrovascular diseases in Ukraine. Ukrainian Medical Journal. 2011;85(5):38-41 [In Ukrainian].

3. Smajlovic D Strokes in young adults epidemiology and prevention. Vascular Health and Risk Management. 2015;11:157-164. doi.org/10.2147/ VHRM.S53203. Feb 2015.

4. Musuka TD Wilton SB Traboulsi M Hill MD Diagnosis and management of acute ischemic stroke: speed is critical. CMAJ : Canadian Medical Association Journal. 2015;187(12):887-893. doi. org/10.1503/cmaj.140355. Aug 2015.

5. Sas A, Horvath L, Olah C, Valikovics A. A. Review of Neuroinflammatory Mechanisms in Ischemic Stroke: Background and Therapeutic Approaches. InMechanisms of Neuroinflammation. 2017. InTech.

6. Lukianchuk VD, Zhytina IO, Seifullina II, Martsinko OE, Pesaroglo OG. Screening and comparative characteristic of anti ischemic e cacy of coordination compounds of germanium in acute cerebrovascular insuficiency Pharmacology and Drug Toxicology [In Ukrainian].

7. Lukianchuk VD, Krylova EV, Seifullina II, Tkachenko VN. Screening of potential cerebroprotectors among newly synthesized coordination compounds of germanium with complexions of hydroxycarboxylic acids in the model of global cerebral ischemia. GO Mozhaev Journal of Emergency Medicine. 2008;9(4):123-126 [In Russian].

8. Gad SC. Drug safety evaluation. John Wiley \& Sons. Accessed 7 Nov 2016.

9. Stefanov OV. Preclinical study of drugs: methodical instructions. K: Avicenna. 2001:292-306.

10. Chadova LV, Seifulina II, Tkachenko VM. Screening and comparative characteristic of anti- ischemic drugs among coordination compounds of germanium with bioligands in acute cerebrovascular insufficiency. Odesa Medical Journal. 2005;6:19-22 [In Ukrainian].

11. Lukianchuk VD, Seifullina II, Litvinenko DF, Martsinko OE. Pharmacodynamics of organic and coordination compounds of germanium - modern state of art Pharmacology and Drug Toxicology. 2016;1:3-13 [In Ukrainian].

12. Shutka AO, Kravets DS, Lukianchuk VD. Mathematical-pharmacological analysis of dose regimen of new antihypoxant OK Ukrainian Journal of Cliniacll and Laboratory Medicine. 2010;5(4):115-9.

13. Canazza A, Minati L, Boffano C, Parati E, Binks S. Experimental models of brain ischemia a review of techniques, magnetic resonance imaging, and investigational cell-based therapies. Front Neurol. Frontiers Media SA. 2014;5:19.

14. Durukan A, Tatlisumak T. Acute ischemic stroke overview of major experimental rodent models, pathophysiology, and therapy of focal cerebral ischemia. Pharmacology Biochemistry and Behavior. 2007;87(1):179-97.

15. Fluri F, Schuhmann MK, Kleinschnitz C. Animal models of ischemic stroke and their application in clinical research. Drug design, development and therapy. 2015;9:3445.

16. Winblad B Piracetam a review of phar macological properties and clinical uses. CNS Drug Rev. 2005;11(2):169-82.

17. Navarro-Mabarak C, Camacho-Carranza R, Espinosa-Aguirre JJ. Cytochrome P450 in the central nervous system as a therapeutic target in neurodegenerative diseases. Drug Metabolism Reviews. 2018;50(2):95-108.

Received: 2018-03-06 